IBIMA Publishing

Journal of e-Learning and Higher Education

https://ibimapublishing.com/articles/JELHE/2021/122637/

Vol. 2021 (2021), Article ID 122637, 6 pages, ISSN : 2169-0359

DOI : $10.5171 / 2021.122637$

Research Article

\title{
SROI Methodology as a Vector of Sports' Development
}

\author{
Andrey V. LITVIN ${ }^{1}$ and Dmitry P. ARKALOV ${ }^{2}$ \\ ${ }^{1} \mathrm{PhD}$ in Economics, Udmurt State University, Izhevsk, Russia \\ ${ }^{2}$ Graduate student, Ural State Economic University, Yekaterinburg, Russia
}

Correspondence should be addressed to: Dmitry P. ARKALOV; lao48@yandex.ru

Received date: 16 September 2020; Accepted date: 25 January 2021; Published date: 9 February 2021

Academic Editor: Natalia Vladimirovna Lazareva

Copyright (C 2021. Andrey V. LITVIN and Dmitry P. ARKALOV. Distributed under Creative Commons Attribution 4.0 International CC-BY 4.0

\begin{abstract}
The study is devoted to the use of the SROI methodology as a determining factor in the effectiveness of the use of budgetary funds provided for sports. Municipal sports' organizations were considered as an applied base. The ratio of financial investments to the number of athletes and sports results made it possible to identify the weaknesses of the current management system, as well as to revise the approach to the formation of the sports structure in the municipality. The division of sports organizations into four categories allowed them to be further optimized, combined and enlarged.
\end{abstract}

keywords: SROI, sport, sports costs.

\section{Introduction}

Social sector developmental investments are designed to cover every system level (federal, regional and local), with the private partnerships being increasingly involved in the investment projects.

This process needs to be supported by the relevant toolkits for calculations and analyses of the relevant performance rates and criteria which, in their turn, require special calculation methodology being applied and tested in practice.
It should be noted that the social investment projects face a variety of challenges both in the public social disbursements and private investment management systems, particularly in the context of the modern business social responsibility concept.

It should also be mentioned that due to the challenges of the modern social investment processes on the whole and the sports sector investments in particular, the above issues still need to be studied in more detail, with the relevant notions being further developed and sorted out whilst many conceptual issues are still being vividly

Cite this Article as: Andrey V. LITVIN and Dmitry P. ARKALOV (2021)," SROI Methodology as a Vector of Sports' Development ", Journal of e-Learning and Higher Education, Vol. 2021 (2021), Article ID 122637, DOI: $10.5171 / 2021.122637$ 
discussed and also waiting for detailed analyses.

A key calculation problem of the social returns on investment projects is due to the difficulties in assessing the project benefits in sound monetary terms.

The traditional rates of investment project benefits are not always applicable, and this is one of the reasons for virtually every social project being now rated as economically inefficient.

On the other hand, sports are known to be highly beneficial for society in many aspects as they effectively cut down the public expenditures for health services and crime prevention services and facilitate integration of the human capital.

Thus, sport contributes to solving many problems for many government agencies and business circles, including promoting a corporate image, developing infrastructure, risks of preventing or mitigating the consequences of civil unrest, etc.

The modern SROI-concept-based investment benefit calculation technology is also not free of certain drawbacks that include the following:

1. the need for a commonly accepted classification of the relevant social values;

2. the available project benefit interpretation and implementation algorithm is still underdeveloped and too complicated;

3. social benefits of the investment projects are rated by a limited range of indicators;

4. some project benefits can hardly be expressed in clear monetary terms.

The modern concept of social return on investments was primarily designed in the early 2000ies by a research team of Roberts Enterprise Development Fund (SanFrancisco, USA) followed by the concept being further developed by the UK-based New Economics Foundation research team that made an attempt to harmonise the SROI concept with the existing social benefits reporting systems.

Currently, there has been little research on the application of the modern SROI concept to assess the social benefits of sports investment projects in Russia.

The purpose of the study was to develop an applied SROI model to clarify the methodology for calculating the social return on government resources invested in the sports sector as part of specific projects (Millar, Hall, 2013).

\section{Methods and structure of the study}

We believe that we need to further standardize the calculation technology within the frame of the base SROI concept and customise the outcome data including a set of special checklists being developed for convenience of the investment project management experts. The main contradiction that needs to be addressed is due to the need for monetary terms/ equivalents or some similar terms and procedures being applied to integrate and harmonise the diverse model characteristics and parameters that can hardly be quantified in practice. There are also many other aspects in the study subject that need to be duly addressed in the study. In the theoretical aspect, the study needs to factor in and analyse the relevant axiological, psychological, sociological, economical and legal components of the process. In addition, the formal calculation procedure cannot be designed unless supported by due mathematical and logical methods, including fuzzy logic methods. In the process management aspect, the study needs to thoroughly analyse the existing decision-making, reporting, planning and forecasting practices. It should be mentioned that the global studies in this area are still making the first steps and, hence, the theoretical basics are still insufficient. The study area may be expanded with time when new statistical data on the country-specific experiences and/or specific social investment projects are reported. Furthermore, studies of this problem need to be governed both by the general methodological principles and more 
specific ones developed within the concept under consideration. Ranked with the former general methodological principles may be the system-approach, determinism, development, relevance, humanism and the individual social responsibility principles. Ranked with the specific ones i.e., developed within the SROI methodology may be the stakeholders' commitment, change monitoring, importance, substantiality, adequate self-rating, transparency and verification principles; and some of the key corporate social responsibility principles (Kazakov and others 2017). Calculations under the modified SROI model will be based on the relevant investment impact and social return data. To further clarify the model itself, the researchers need to mine the statistical data relating to the traditional SROI model parameters. Having designed the new mathematical model, we can further clarify the list of the necessary parameters. These parameters (invested amount, for example) may be classified into two groups: expected and actual. The actual data may be mined from the official sources and by the relevant questionnaire survey (opinion polling) methods, with the questionnaire forms being distributed via email to speed up and save costs of the process. The expected data for each of the parameters may be also mined via polling, with the process outcomes being additionally discussed in the focus groups. A representative sample will include at least 50-60 respondents. The proposed procedure will be designed to ensure due authenticity, dependability and interpretability of the outcome data.

\section{Research}

We have conducted research to assess the social effectiveness of financing sports organizations based on the SROI concept (Litvin and others 2019). As an empirical base, data are used on sports schools in Izhevsk for 2017-2018 (table 1). The data were obtained on the basis of the state statistical reporting form $5 \mathrm{FK}$ «Information about the sports school», and from the official open site for posting information on the financial and economic activities of state (municipal) institutions bus.gov.ru. To process the information, methods of calculating average values, grouping, correlation analysis, Data Mining was applied. The analysis showed that between sports schools there are significant differences in terms of the social efficiency of investments - the number of athletes and the number of gold medals per 1 ruble invested in financing sports schools of budgetary funds. From the position of the SROI concept, there is considerable potential for optimizing the financing of certain sports and in improving the performance of sports schools (Ponkin, 2017). A model for grouping sports schools according to the level of social efficiency of investments is formed; based on the available sample, four categories of sports schools with different parameters of social efficiency of investments in sports are identified. At present, it is important to improve methods for calculating indicators of the social efficiency of using funds allocated to specific sports facilities, sports, sports events, etc. These problems must find their place in the framework of training professional sports managers (Howard, Cromptonб 2018). 
Table 1: Indicators of sports schools in Izhevsk

\begin{tabular}{|c|c|c|c|c|c|c|}
\hline $\begin{array}{c}\text { Sports } \\
\text { School } \\
\text { Code }\end{array}$ & $\begin{array}{c}\text { The cost of } \\
\text { maintainin } \\
\text { g a sports } \\
\text { school, } \\
\text { thousand } \\
\text { rubles }\end{array}$ & $\begin{array}{c}\text { Numbe } \\
\text { Athlete } \\
\text { s }\end{array}$ & $\begin{array}{c}\text { Costs } \\
\text { per } \\
\text { Athlet } \\
\text { e }\end{array}$ & $\begin{array}{c}\text { The ratio of athletes } \\
\text { studying to } \\
\text { «excellent» and } \\
\text { «good» to the total } \\
\text { number of athletes } \\
\text { Russian system for } \\
\text { assessing knowledge } \\
\text { at school) }\end{array}$ & $\begin{array}{c}\text { The number of } \\
\text { gold medals at } \\
\text { the All-Russian } \\
\text { competitions } \\
\text { per athlete }\end{array}$ & $\begin{array}{c}\text { The number } \\
\text { of gold } \\
\text { medals at the } \\
\text { All-Russian } \\
\text { competitions }\end{array}$ \\
\hline $\mathbf{1}$ & 17936,20 & 984 & 18,23 & 0,58 & 0,021 & 21 \\
\hline $\mathbf{2}$ & 14655,70 & 555 & 26,41 & 0,63 & 0,000 & 0 \\
\hline $\mathbf{3}$ & 20717,80 & 753 & 27,51 & 0,63 & 0,008 & 6 \\
\hline $\mathbf{4}$ & 19250,30 & 949 & 20,28 & 0,21 & 0,005 & 5 \\
\hline $\mathbf{5}$ & 11130,80 & 705 & 15,79 & 0,48 & 0,000 & 0 \\
\hline $\mathbf{6}$ & 10181,80 & 732 & 13,91 & 0,70 & 0,003 & 2 \\
\hline $\mathbf{7}$ & 33699,00 & 826 & 40,80 & 0,40 & 0,011 & 9 \\
\hline $\mathbf{8}$ & 12267,90 & 312 & 39,32 & 0,53 & 0,054 & 17 \\
\hline $\mathbf{9}$ & 10701,00 & 259 & 41,32 & 0,41 & 0,000 & 0 \\
\hline $\mathbf{1 0}$ & 7349,40 & 325 & 22,61 & 0,52 & 0,006 & 2 \\
\hline $\mathbf{1 1}$ & 8920,90 & 531 & 16,80 & 0,58 & 0,064 & 34 \\
\hline $\mathbf{1 2}$ & 10395,90 & 355 & 29,28 & 0,59 & 0,006 & 2 \\
\hline $\mathbf{1 3}$ & 5170,30 & 97 & 53,30 & 0,49 & 0,000 & 0 \\
\hline $\mathbf{1 4}$ & 36866,20 & 1156 & 31,89 & 0,44 & 0,007 & 8 \\
\hline $\mathbf{1 5}$ & 10329,60 & 407 & 25,38 & 0,76 & 0,000 & 0 \\
\hline $\mathbf{1 6}$ & 3469,10 & 43 & 80,68 & 0,05 & 0,023 & 1 \\
\hline $\mathbf{1 7}$ & 24188,70 & 1590 & 15,21 & 0,89 & 0,000 & 0 \\
\hline $\mathbf{1 8}$ & 16177,50 & 621 & 26,05 & 0,54 & 0,031 & 19 \\
\hline $\mathbf{1 9}$ & 19083,50 & 492 & 38,79 & 0,82 & 0,026 & 13 \\
\hline $\mathbf{2 0}$ & 8817,10 & 552 & 15,97 & 0,90 & 0,013 & 7 \\
\hline & & & & & & \\
\hline
\end{tabular}

The costs of maintaining sports schools, the number of athletes, and the number of winners, were obtained on the basis of the reported statistical information (statistical reporting form $5 \mathrm{FK}$ «Information about the sports school», the official website for posting information on state (municipal) institutions bus.gov.ru).

The share of student athletes who study «excellent» and «good» in the contingent of students is determined using a survey of the heads of sports schools. For the analysis of the social effectiveness of investments in the activities of sports schools for each sports school, the expenses for one athlete are calculated, as well as the number of gold medals at the All-Russian competitions for one athlete. In the future, the ratio of the number of gold medals to the volume of financing («the price of one victory») was also calculated. From the point of view of social efficiency, the correlation between the sporting success of a sports school the ratio of the number of gold medals to the number of athletes) and success in getting an education at school (the share of «excellent students» and «good») is of interest. To conduct the study, traditional methods of applied multivariate statistical analysis Data Mining were used. The peculiarity of this group of methods is that they do not require preliminary formulation of hypotheses, for this reason they are referred to as «exploratory analysis».

\section{Research results and discussion}

All sports schools are divided into two groups according to the cost of one athlete 
(table. 2). The average cost is the median of 26230,00 rubles. The arithmetic mean value of costs in the 1 st group is 19020 rubles, in the 2 nd $-40030,00$ rubles.

Table 2: Grouping of sports schools by the level of costs per athlete

\begin{tabular}{|l|c|c|}
\hline \multicolumn{1}{|c|}{ Data } & 1st group & 2nd group \\
\hline Sports School Code & $\begin{array}{c}6 ; 17 ; 5 ; 20 ; 11 ; 1 ; 4 ; 10 ; \\
15 ; 18\end{array}$ & $\begin{array}{c}2 ; 3 ; 12 ; 19 ; 8 ; 7 ; 9 ; 13 ; \\
16\end{array}$ \\
\hline $\begin{array}{l}\text { Average costs for a group of sports schools } \\
\text { per athlete, thousand rubles }\end{array}$ & 19,02 & 40,93 \\
\hline
\end{tabular}

The data in the table indicate that between the two groups of sports schools there is a double gap in costs per athlete, due to the difference in sports, and in differences in the effectiveness of cost management between sports schools. We will construct a similar table for the number of gold medals per unit of financing (Table 3). The median value in the sample is 0,26 (zero point two six). In this case, there is an eightfold gap between the two groups of sports schools, which indicates a very significant difference in the "price of victory». The reasons for this require further study. It should be noted that in the 1st group sports schools with mainly playing sports are concentrated.

Table 3: Grouping of sports schools by the number of gold medals per 1 million rubles of budget financing

\begin{tabular}{|l|c|c|}
\hline \multicolumn{1}{|c|}{ Indicators } & 1st group & 2nd group \\
\hline Sports School Code & $\begin{array}{c}17 ; 5 ; 15 ; 2 ; 9 ; 13 ; 12 ; 7 ; 10 ; 16 ; 3 ; 19 ; 20 ; 1 ; \\
6 ; 14 ; 4\end{array}$ & $18 ; 8 ; 11$ \\
\hline $\begin{array}{l}\text { The average number of gold medals per 1 million } \\
\text { rubles of budget funding for a sports school, for a } \\
\text { group of schools }\end{array}$ & 0,11 & 0,87 \\
\hline
\end{tabular}

We summarize both tables in table 4 .

Table 4 allows you to identify four categories of objects - with an efficiency higher than the average for two positions; with efficiency below average in two positions; two categories in an intermediate position. The most effective category (bottom left of the table) includes primarily individual sports, martial arts, athletics

Table 4: Grouping of sports schools by two indicators of social efficiency of investments

\begin{tabular}{|l|c|c|}
\hline \multicolumn{1}{|c|}{ Indicators } & $\begin{array}{c}\text { The cost per athlete is below } \\
\text { average }\end{array}$ & $\begin{array}{c}\text { The cost per athlete is above } \\
\text { average }\end{array}$ \\
\hline $\begin{array}{l}\text { The number of gold medals per } 1 \\
\text { million rubles of budget costs is } \\
\text { below average }\end{array}$ & $6 ; 17 ; 5 ; 4 ; 15$ & $2 ; 12 ; 14 ; 9 ; 13$ \\
\hline $\begin{array}{l}\text { The number of gold medals per } 1 \\
\text { million rubles of budget costs is } \\
\text { above average }\end{array}$ & $20 ; 11 ; 1 ; 10 ; 18$ & $3 ; 19 ; 8 ; 7 ; 16$ \\
\hline
\end{tabular}

It should be noted that the assignment of an object to one of the categories can be explained by both natural causes (for example, features of a sport) and the effectiveness of managing a sports school.
In any case, from the point of view of the SROI concept, special attention should be paid to those positions (sports, sports schools) that provide the highest return on investment. 


\section{Findings}

There are significant differences between sports schools in terms of indicators of the social efficiency of investments. In this case, the gap in costs per athlete between the two groups of sports schools was 2 times; the discrepancies in the number of gold medals per unit of expenditure exceeded 8 times. From the position of the SROI concept, in this case, there is considerable potential for optimizing the financing of certain sports and increasing the efficiency of sports schools. In the course of analysis, a model for assessing the social effectiveness of investments was formed and four categories of sports schools with different parameters of the social effectiveness of investments in sports were identified. The factors that caused a particular school to fall into the appropriate category, as well as the necessary conclusions for management, require additional research. Our study did not confirm the hypothesis that there is a correlation between sports and educational success of athletes in the context of sports (the correlation coefficient was - 0,07). At the same time, it can take place within certain sports or among athletes in a specific organization.

\section{References}

- Howard, D., Crompton J. (2018). FINANCING SPORT fourth edition. Virginia del Oeste. FiT Publishing a Division of ICPE/WVU-CPASS.

- $\quad$ Kazakov, A.N., Litvin, A.V., Esipovich, L. (2017). SOCIAL RETURN ON INVESTMENTS (SROI) IN SPORTS: MODIFIED MODEL. Theory and Practice of Physical Culture, 1. 14.

- Litvin, A.V., Arkalov, D.P., Ryabcev, A.V. (2019). «SROI Based Sport School Performance Efficiency Rating Analysis'» Book of Abstracts of the 3rd WORLD ASSOCIATION FOR SPORT MANAGEMENT WORLD CONFERENCE, Santiago de Chile, Chile, 45-46.

- $\quad$ Millar, R., Hall, K. (2013). Social Return on Investment (SROI) and Performance Measurement, Public Management Review, 15(6), 923-941.

- Ponkin, I.V. (2017). State administration in the field of sports. Master's textbook. Moscow, Buki Vedi. 